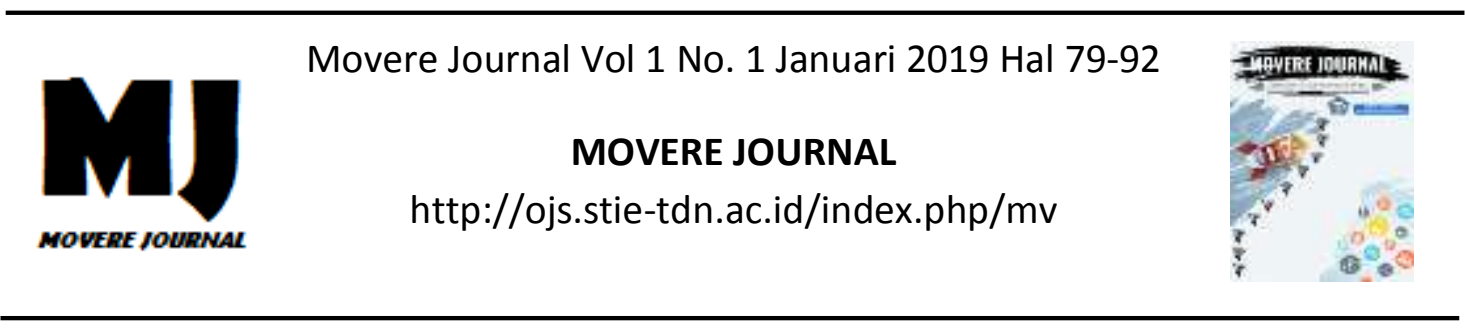

\title{
FAKTOR-FAKTOR BERPENGARUH TERHADAP KINERJA KARYAWAN PADA PT GARUDA INDONESIA KANTOR CABANG MAKASSAR
}

\author{
Risnayanti Andi Djamro' ${ }^{1)}$, Aprizal ${ }^{2)}$ \\ STIMIK Dipanegara
}

\begin{abstract}
Abstrak : Tujuan penelitian ini adalah 1) untuk mengetahui dan menganalisis pengaruh budaya organisasi terhadap kinerja karyawan pada PT Garuda Indonesia Kantor Cabang Makassar, 2) untuk mengetahui dan menganalisis pengaruh kepuasan kerja terhadap kinerja karyawan pada PT Garuda Indonesia Kantor Cabang Makassar, 3) untuk mengetahui dan menganalisis pengaruh motivasi kerja terhadap kinerja karyawan pada PT Garuda Indonesia Kantor Cabang Makassar, dan 4) untuk mengetahui dan menganalisis pengaruh lingkungan kerja terhadap kinerja karyawan pada PT Garuda Indonesia Kantor Cabang Makassar. Metode analisis yang digunakan dalam penelitian ini adalah metode analisis Regresi Berganda. Data penelitian diperoleh dari karyawan pada PT Garuda Indonesia Kantor Cabang Makassar. Pendekatan penelitian adalah pendekatan kausal yang bersifat explanatory. Hasil penelitian ini menunjukkan bahwa: 1) budaya organisasi berpengaruh positif dan signifikan terhadap kinerja karyawan pada PT Garuda Indonesia Kantor Cabang Makassar. Hal ini berarti semakin baik budaya organisasi maka semakin meningkat kinerja karyawan, 2) kepuasan kerja berpengaruh positif dan signifikan terhadap kinerja karyawan pada PT Garuda Indonesia Kantor Cabang Makassar. Hal ini berarti kepuasan kerja yang dirasakan oleh karyawan akan meningkatkan kinerja karyawan, 3) motivasi kerja berpengaruh positif dan signifikan terhadap kinerja karyawan pada PT Garuda Indonesia Kantor Cabang Makassar. Hal ini berarti motivasi kerja dapat memberikan semangat kepada karyawan untuk meningkatkan kinerjanya, dan merupakan variabel yang paling dominan berpengaruh terhadap kinerja karyawan dan 4) Lingkungan kerja berpengaruh positif dan signifikan terhadap kinerja karyawan pada PT Garuda Indonesia Kantor Cabang Makassar. Hal ini berarti lingkungan kerja yang kondusif dapat meningkatkan kinerja karyawan.
\end{abstract}

Kata kunci: budaya organisasi, kepuasan kerja, motivasi kerja, lingkungan kerja dan kinerja karyawan

\section{PENDAHULUAN}

Budaya organisasi yang baik, kepuasan kerja yang dirasakan oleh semua karyawan, motivasi kerja yang memberikan semangat dan lingkungan kerja yang sehat merupakan bagian dari faktor-faktor yang dapat mempengaruhi terciptanya kinerja karyawan. Menurut Robbins (2008:271) budaya organisasi adalah mengacu ke sistem makna bersama yang dianut oleh anggota-anggota yang membedakan organisasi itu dari organisasi-organisasi lain. Budaya organisasi yang ada di PT. Garuda Indonesia (Persero) Tbk Cabang Makassar tidak terlepas dari prinsipprinsip FLY HI yaitu effecient \& effective, loyalty, customer centricity, honesty \& opennes, dan integrity. 
Effecient \& effective berkaitan dengan keakuratan, penghematan, dan ketepatan waktu dalam bekerja. Loyalty berkaitan dengan dedikasi dan tanggung jawab yang ditunjukkan dari sikap disiplin, bekerja keras dan tuntas. Customer centricity berkaitan dengan pemberian pelayanan yang tulus dengan mengutamakan kepuasan pelanggan. Honesty \& openness berkaitan dengan menjunjung tinggi kejujuran, ketulusan, keterbukaan dengan tetap memungkinkan ketersediaan informasi. Integrity berkaitan dengan menjaga harkat dan martabat serta menghindarkan diri dari perbuatan tercela yang dapat merusak citra perusahaan.

Singh dan Jain (2013:106) mengatakan bahwa kepuasan kerja sebagai respon afektif atau emosional terhadap berbagai aspek pekerjaan karyawan. Jika karyawan dalam suatu organisasi merasa bahagia, mereka akan melakukan yang terbaik bagi organisasinya. Kepuasan kerja karyawan PT. Garuda Indonesia (Persero) Tbk Cabang Makassar salah satunya adalah berkaitan dengan dedikasi dan tanggung jawab yang ditunjukkan dari sikap disiplin, bekerja keras dan tuntas. Sikap disiplin yang ada diperusahaan tergolong rendah, dikarenakan masih banyak karyawan yang sering datang terlambat dan tidak mematuhi peraturan seperti tidak mau menggunakan finger print untuk absensi. Hal ini menunjukkan bahwa penggunaan finger print belum dilakukan secara efektif. Berdasarkan hasil wawancara dengan sebagian karyawan ditemukan bahwa karyawan cenderung menggunakan absensi secara manual dikarenakan tidak adanya pengawasan absensi dengan media finger print.

Mathis (2011:114), pemberian motivasi kerja yang makin baik dapat mendorong karyawan bekerja dengan makin produktif. Kejelasan arah tersebut dapat diberikan oleh pihak perusahaan atau manajer, sehingga karyawan mengetahui apa yang menjadi tujuannya dalam melakukan usaha menyelesaikan pekerjaannya. Pada perusahaan PT. Garuda Indonesia (Persero) Tbk Cabang Makassar, ditemukan bahwa karyawan yang keluar dikarenakan karyawan tersebut mengundurkan diri. Hal ini menunjukkan rendahnya motivasi kerja karyawan yang ada. Status karyawan yang seharusnya diperoleh dari pekerjaan antara lain ditunjukkan oleh klasifikasi jabatan, hak-hak istimewa yang diberikan, serta peralatan dan lokasi kerja yang dapat menunjukkan statusnya. Namun kenyataannya karyawan merasa tidak adanya jaminan karir ataupun promosi jabatan yang jelas.

Lingkungan kerja yang dapat menciptakan hubungan kerja yang mengikat antara orang-orang yang ada di dalam lingkungannya (Sedarmayanti, 2011:2). Lingkungan fisik kerja tergolong baik, hal ini dapat dilihat dari fasilitas yang ada pada PT. Garuda Indonesia (Persero) Tbk Cabang Makassar dalam keadaan bersih, tidak bising, luasnya ruang kerja, dan sirkulasi udara yang baik serta terdapat peralatan yang memadai sesuai dengan standar yang telah ditetapkan perusahaan. Sedangkan lingkungan non fisik khususnya hubungan antar karyawan yang memiliki konflik dalam bekerja seperti kurangnya interaksi antara karyawan dalam bekerja, sikap acuh tak acuh antar karyawan, banyaknya beban kerja dan adanya pekerjaan yang merangkap yang dikerjakan karyawan. Hal ini menunjukkan bahwa adanya interaksi kerja yang buruk baik antar satu unit kerja maupun antar unit kerja. Perusahaan dalam upaya untuk mewujudkan tujuan perusahaan, salah satunya adalah dengan mempunyai karyawan yang memiliki kinerja yang 
baik. Menurut Mondy (2010:256) kinerja adalah proses berorientasi tujuan yang diarahkan untuk memastikan bahwa proses-proses keorganisasian ada pada tempatnya untuk memaksimalkan produktivitas para karyawan, tim dan akhirnya organisasi. Sistem penilaian kategori kinerja PT. Garuda Indonesia (Persero) Tbk Cabang Makassar dinamakan rating scale, yaitu pencatatan keputusan tentang kinerja dalam suatu skala berdasarkan kuantitas, kualitas dan kehadiran karyawan. Namun evaluasi dari hasil penilaian kinerja selama ini tidak dijalankan sebagaimana mestinya sehingga aspek transparansi, adil, objektif dan umpan balik tidak dilakukan kepada karyawan dan karyawan tidak mengetahui adanya pelaksanaan penilaian kinerja yang dilakukan personalia.

\section{KERANGKA KONSEP Budaya Organisasi}

Budaya organisasi yaitu bagaimana anggota atau sekelompok karyawan mampu menghadapi masalah eksternal dan internal, maka dari itu budaya organisasi harus dikembangkan dan diajarkan kepada anggota agar dijadikan pedoman tingkah laku bagi anggota-anggota dalam menghadapi masalah. Mangkunegara (2012:113) menyatakan bahwa budaya organisasi adalah merupakan peraturan atau pandangan yang diyakini oleh karyawan dalam perusahaan, dimana terdapat aturan yang harus ditaati untuk kepentingan bersama. Sedarmayanti (2011:89), budaya organisasi adalah sebuah keyakinan, sikap dan nilai yang umumnya dimiliki, yang timbul dalam organisasi. Budaya organisasi dapat didefinisikan sebagai perangkat sistem nilai-nilai (values), keyakinan- keyakinan, asumsi-asumsi atau normanorma yang telah lama berlaku, disepakati dan diikuti oleh para anggota suatu organisasi sebagai pedoman perilaku dan pemecahan masalah- masalah organisasi (Darodjat, 2015:236). Priansa dan Garnida (2013:77) berpendapat bahwa budaya organisasi merupakan sistem nilai yang dikembangkan dan berlaku dalam suatu organisasi, yang menjadikan ciri khas sebagai sebuah organisasi. Budaya organisasi merupakan suatu system bermakna bersama yang dianut oleh anggota-anggota yang membedakan organisasi satu dengan organisasi lainnya. Sistem makna bersama tersebut bila diamati dengan lebih seksama merupakan seperangkat karakteristik utama yang dihargai oleh organisasi itu.

Mc Shane dan Glinow (2008:460) mengatakan, bahwa budaya organisasi yang kuat memiliki potensi meningkatkan kinerja, dan sebaliknya bila budaya organisasinya lemah mengakibatkan kinerja menurun. Budaya organisasi memiliki tiga fungsi penting yaitu sebagai sistem pengawasan, perekat hubungan sosial, dan saling memahami. Berdasarkan beberapa pengertian tersebut maka ditarik kesimpulan bahwa pengertian budaya organisasi merupakan seperangkat asumsi atau system keyakinan, nilai-nilai dan norma yang dianut oleh setiap anggota organisasi yang dijadikan sebagai pedoman membentuk dan mengarahkan perilaku dalam mengatasi masalah akibat adanya perubahan.

\section{Kepuasan Kerja}

Kepuasan kerja adalah suatu tingkatan perasaan yang positif atau negatif tentang beberapa aspek dari pekerjaan, situasi kerja, dan hubungan dengan rekan sekerja. Menurut Hasibuan (2011:202), kepuasan kerja adalah sikap emosional yang menyenangkan dan mencintai 
pekerjaannya. Kepuasan kerja (job statisfaction) karyawan harus diciptakan sebaik-baiknya supaya moral kerja, dedikasi, kecintaan, dan kedisiplinan karyawan perusahaan meningkat. Sikap ini dicerminkan oleh moral kerja, kedisiplinan, dan prestasi kerja. Kepuasan kerja dinikmati dalam pekerjaan, luar pekerjaan, dan kombinasi dalam dan luar pekerjaan (Martoyo, 2014:132).

Kepuasan kerja dalam pekerjaan adalah kepuasan kerja yang dinikmati dalam pekerjaan dengan memperoleh pujian hasil kerja, penempatan, perlakuan, peralatan, dan suasana lingkungan kerja yang baik. Karyawan yang lebih suka menikmati kepuasan kerja dalam pekerjaan akan lebih mengutamakan pekerjaannya daripada balas jasa walaupun balas jasa itu penting. Menurut Kreitner dan Kinicki (2011:271) kepuasan kerja adalah suatu efektifitas atau respons emosional terhadap berbagai aspek pekerjaan. Kepuasan kerja merupakan respon afektif atau emosional terhadap berbagai segi atau aspek pekerjaan seseorang sehingga kepuasan kerja bukan merupakan konsep tunggal. Seseorang dapat relatif puas dengan salah satu aspek pekerjaan dan tidak puas dengan satu atau lebih aspek lainnya.

Gomes (2008:281), kepuasan kerja itu sendiri dapat diartikan sebagai hasil kesimpulan yang didasarkan pada perbandingan mengenai apa yang secara nyata diterima oleh pegawai dari pekerjaannya dibandingkan dengan apa yang diharapkan, diinginkan dan dipikirkan sebagai hal yang pantas atau berhak baginya. Martoyo, (2014:35) memandang kepuasan kerja sebagai hasil keseluruhan dari derajat rasa suka atau tidak sukanya tenaga kerja terhadap berbagai aspek dari pekerjaannya yaitu aspek-aspek seperti gaji atau upah yang diterima, kondisi kerja dan sikap pimpinan. Dengan kata lain, kepuasan kerja mencerminkan sikap tenaga kerja terhadap pekerjaannya.

Robbins (2008:78) kepuasan kerja adalah sikap umum terhadap pekerjaan seseorang yang menunjukkan perbedaan antara jumlah penghargaan yang diterima pekerja dan jumlah yang mereka yakini seharusnya mereka terima. Kepuasan Kerja merupakan sikap (positif) tenaga kerja terhadap pekerjaannya, yang timbul berdasarkan penilaian terhadap situasi kerja. Penilaian tersebut dapat dilakukan terhadap salah satu pekerjaannya, penilaian dilakukan sebagai rasa menghargai dalam mencapai salah satu nilai-nilai penting dalam pekerjaan. Karyawan yang puas lebih menyukai situasi kerjanya daripada tidak menyukainya.

\section{Motivasi Kerja}

Motivasi mempersoalkan bagaimana cara menggerakkan daya dan potensi agar bekerja mencapai tujuan yang ditentukan (Hasibuan, 2011:92). Pada dasarnya seorang bekerja karena keinginan memenuhi kebutuhan hidupnya. Dorongan keinginan pada diri seseorang dengan orang lain yang berbeda sehingga perilaku manusia cenderung beragam di dalam bekerja.

Motivasi adalah keadaan pribadi seseorang yang mendorong keinginan individu melakukan kegiatan tertentu guna mencapai suatu tujuan motivasi kerja berkaitan dengan hasil kerja individual sekaligus mempengaruhi kinerja organisasi. Hartatik (2014:162) motivasi kerja merupakan suatu perangsang keinginan dan daya penggerak kemauan yang menciptakan kegairahan seseorang untuk mencapai suatu tujuan yang dikehendaki. Motivasi memberi karyawan bimbingan, arahan, sumber daya dan imbalan agar mereka terinspirasi dan tertarik untuk bekerja dengan cara yang perusahaan inginkan. 
Motivasi adalah menemukan kebutuhan karyawan dan membantu untuk mencapainya. Memotivasi karyawan bertujuan untuk memperluas keterampilan mereka dalam memenuhi tuntutan organisasi. Motivasi menurut Hasibuan (2011:92) adalah pemberian daya penggerak yang menciptakan kegairahan kerja seseorang, agar mau bekerja sama, bekerja efektif dan terintegrasi dengan segala daya upayanya untuk mencapai kepuasan. Pengertian motivasi kerja menurut Handoko (2008:184) yaitu suatu tenaga atau faktor yang terdapat di dalam diri manusia, yang menimbulkan, mengarahkan, dan mengorganisasikan tingkah lakunya.

Robbins

(2008:156)

menyatakan motivasi sebagai proses yang menyebabkan intensitas (intensity), arah (direction), dan usaha terus-menerus (persistence) individu menuju pencapaian tujuan. Motivasi merupakan ukuran berapa lama seseorang dapat menjaga usaha mereka. Individu yang termotivasi akan menjalankan tugas cukup lama untuk mencapai tujuan mereka. Pemberian motivasi kerja diharapkan dapat meningkatkan kinerja karyawan terhadap perusahaan yang dapat dilihat dari aspek-aspek atau dimensi kepuasan kerja, budaya organisasi dan pola kepemimpinan yang diperoleh. Hal ini diharapkan dapat menciptakan hasil kerja secara kualitas dan kuantitas yang dicapai oleh karyawan dalam melaksanakan tugasnya sesuai dengan tanggung jawab yang diberikan kepadanya yang nantinya mempengaruhi kinerja.

Siagian (2012:102), motivasi merupakan daya dorong bagi seseorang untuk memberikan kontribusi yang sebesar mungkin demi keberhasilan organisasi dalam mencapai tujuan. Dapat diartikan bahwa adanya dorongan pada seseorang akan memberikan kontribusi pada organisasinya sebesar mungkin dalam mencapai tujuan. Maka dapat disimpulkan motivasi adalah adanya dorongan yang ada pada diri seseorang untuk melakukan suatu perbuatan untuk mencapai tujuan yang diinginkan.

\section{Lingkungan Kerja}

Salah satu faktor yang mempengaruhi kinerja adalah lingkungan kerja. Menurut Nitisemito (2012:183) menyatakan lingkungan kerja adalah segala sesuatu yang ada disekitar para pekerja yang dapat mempengaruhi dirinya dalam menjalankan tugas-tugas yang diembankan. Untuk mengoptimalkan kinerja karyawan harus tercipta lingkungan kerja yang kondusif sebagai prasyarat peningkatan kinerja karyawan secara maksimal. Kondisi lingkungan kerja yang baik akan membuat karyawan dapat melaksanakan pekerjaannya secara optimal, sehat, aman dan nyaman sehingga terciptanya kinerja karyawan yang baik. Sedarmayanti (2011:1) menyatakan bahwa lingkungan kerja sebagai keseluruhan alat perkakas dan bahan yang dihadapi, lingkungan sekitarnya di mana seseorang bekerja, metode kerjanya, serta pengaturan kerjanya baik sebagai perseorangan maupun sebagai kelompok.

Robbins dan Judge (2011:170) lingkungan kerja adalah segala sesuatu yang berada di lingkungan yang dapat mempengaruhi baik secara langsung maupun tidak langsung seseorang atau sekelompok orang di dalam melaksanakan aktivitasnya. Menurut Mangkunegara (2012:17) lingkungan kerja yang dimaksud antara lain uraian jabatan yang jelas, target kerja yang menantang, pola komunikasi kerja yang efektif, iklim kerja dan fasilitas kerja yang relatif memadai. Sehingga dapat disimpulkan bahwa lingkungan kerja merupakan segala sesuatu yang 
ada di sekitar manusia, yang dapat memberikan pengaruh dalam beraktivitas dan bertindak, baik secara langsung maupun tidak langsung dalam melaksanakan kegiatan seharihari serta mempunyai pengaruh yang cukup besar terhadap jalannya suatu sistem kerja yang baik di dalam lingkungna kerja suatu perusahaan.

Rivai (2009:150), lingkungan kerja yang aman dan sehat akan membawa dampak yang positif bagi orang-orang yang berada di dalamnya. Manfaat lingkungan kerja yang aman dan sehat akan meningkatkan produktivitas, karena menurunnya jumlah hari yang hilang, meningkatkan efisiensi dan kualitas pekerja yang lebih berkomitmen, menurunkan biaya-biaya kesehatan dan asuransi, tingkat kompensasi pekerja dan pembayaran langsung yang lebih rendah karena menurunnya pengajuan klaim, fleksibilitas dan adaptabilitas yang lebih besar sebagai akibat dari meningkatnya partisipasi dan rasa kepemilikan, serta rasio seleksi tenaga kerja yang lebih baik karena naiknya citra perusahaan.

Lingkungan kerja adalah suatu kondisi dimana para karyawan bekerja dalam suatu perusahaan yang dapat mempengaruhi kondisi fisik dan psikologi karyawan baik secara langsung maupun tidak langsung sehingga lingkungan kerja dapat dikatakan baik apabila karyawan dapat bekerja dengan optimal, tenang dan produktivitasnya tinggi. Jika lingkungan kerja yang kondusif maka karyawan bisa aman, nyaman dan jika lingkungan kerja tidak mendukung maka karyawan tidak bisa aman dan nyaman. Lingkungan kerja sangat berpengaruh terhadap pekerjaan yang dilakukan karyawan. Sehingga setiap perusahaan haruslah mengusahakan lingkungan kerja yang sedemikian rupa agar memberikan pengaruh positif terhadap pekerjaan yang dilakukan karyawan.

\section{Kinerja Karyawan}

Kinerja atau performance merupakan gambaran mengenai tingkat pencapaian suatu pelaksanaan suatu program kegiatan atau kebijakan dalam mewujudkan sasaran, tuijuan, visi dan misi organisasi yang di tuangkangan melalui perencanaan suatu strategi organisasi. Kinerja menurut Scriber, Bantam. English Dictionary dalam Moeharianto (2012:89), menjelaskan bahwa kinerja berasal dari kata to perform dengan beberapa entitas yaitu: (1) melakukan, menjelaskan, melaksanakan (to do or carry of a execute). (2) memenuhinatau melaksakan kewajiban atau nazar (to do discharge of fulfil as vow). (3) melaksanakan atau menyempurnakan tanggung jawab (to execute or complete of an undrestan king). (4) melakukan sesuatu yang di harapkan oleh seseorang atau mesin (to do what is expected of a person machine).

Teori human capital menjelaskan bahwa orang yang memiliki keterampilan, pengetahuan, dan kemampuan akan memberikan nilai ekonomis pada perusahaan. Investasi perusahaan banyak digunakan untuk meningkatkan keterampilan, pengetahuan, dan kemampuan karyawan. Untuk menjaga kelangsungan hidup perusahaan agar mampu bersaing dan agar tujuan strategis perusahaan bisa tercapai perlu untuk menjaga kinerja karyawan tetap optimal. Pengertian kinerja menurut Mangkunegara (2012:9) adalah hasil kerja atau prestasi kerja baik kualitas maupun kuantitas yang dicapai sumber daya manusia persatuan periode waktu dalam melaksanakan tugas kerjanya sesuai dengan tanggung jawab yang diberikan.

Rosyida (2010), kinerja atau performance sebagai hasil kinerja yang 
dapat dicapai oleh seseorang atau kelompok orang dalam suatu perusahaan/organisasi baik secara kualitatif maupun secara kuantitatif, sesuai dengan kewewenangan, tugas dan tanggung jawab masing-masing dalam upaya mencapai tujmuan organisasi bersangkutan secara legal, tidak melanggar hukum dan sesuai dengan moral ataupun etika. Hasibuan (2011:167), kinerja adalah hasil kerja secara kualitas dan kuantitas yang dicapai oleh seorang karyawan dalam melaksanakan tugasnya sesuai dengan tanggung jawab yang diberikan kepadanya. Kinerja mencakup segi usaha, loyalitas, potensi, kepemimpinan, dan moral kerja. Ditingkat manapun tidak ada satu ukuran kriteria yang tepat merefleksikan kinerja (Gibson, 2008:18).

Kinerja merupakan ekspresi potensi seseorang dalam memenuhi tanggungjawabnya dengan menetapkan standar tertentu. Sinambela. dkk (2012:137), kinerja adalah hasil kerja yang dapat dicapai oleh karyawan atau sekelompok karyawan dalam organisasi, sesuai dengan wewenang dan tanggung jawab masing-masing, dalam upaya mencapai tujuan organisasi bersangkutan secara legal, tidak melanggar hukum dan sesuai dengan moral dan etika. Kinerja yang baik merupakan cerminan dari perilaku yang baik sehingga dengan kinerja yang baik akan membuahkan produktivitas yang baik yang nantinya dapat mencapai tujuan organisasi (Nitisemito, 2012:25).

Berdasarkan konsep dan pendapat para ahli diatas, maka peneliti mendefinisikan kinerja adalah kemampuan seseorang secara kualitas dan kuantitas dalam melaksanakan tugasnya dalam rangka mewujudkan tujuan organisasi. Selain itu juga kinerja karyawan adalah hasil kerja seorang karyawan dalam menjalankan tugas dan tanggung jawabnya dalam rangka mewujudkan tujuan organisasi.

\section{METODE PENELITIAN}

\section{Lokasi dan Waktu Penelitian}

Lokasi penelitian yang dipilih dalam penelitian ini adalah PT Garuda Indonesia Kantor Cabang Makassar. Waktu penelitian dilaksanakan selama 3 (tiga) bulan yaitu mulai bulan September sampai bulan Desember 2017.

\section{Populasi dan Sampel}

Populasi dalam penelitian ini adalah karyawan pada PT Garuda Indonesia Kantor Cabang Makassar yang berjumlah 95 orang. Teknik yang digunakan dalam penelitian ini adalah teknik sampling jenuh (sensus) dimana semua responden dijadikan sampel. Jadi sampel dalam penelitian ini adalah 95 karyawan.

\section{Metode Analisis}

Analisis dengan alat statistik ini digunakan untuk mengetahui pengaruh variabel independen $(\mathrm{X})$ terdiri dari variabel budaya organisasi, kepuasan kerja, motivasi kerja, lingkungan kerja terhadap variabel dependen (Y) yaitu kinerja karyawan. Sugiyono (2013:103), untuk menguji hipotesis dalam penelitian ini, maka digunakan model sebagai berikut:

$\mathbf{Y}=\mathbf{a}+\mathbf{b}_{1} \mathbf{X}_{1}+\mathbf{b}_{2} \mathbf{X}_{2}+\mathbf{b}_{3} \mathbf{X}_{3}+\mathbf{b}_{4} \mathbf{X}_{4}+\mathbf{e}$

Dimana :

$$
\begin{array}{ll}
\mathrm{Y} & =\text { Kinerja Karyawan } \\
\mathrm{X}_{1} & =\text { Budaya Organisasi } \\
\mathrm{X}_{2} & =\text { Kepuasan Kerja } \\
\mathrm{X}_{3} & =\text { Motivasi Kerja } \\
\mathrm{X}_{4} & =\text { Lingkungan Kerja } \\
\mathrm{a} & =\text { Bilangan Konstanta } \\
\mathrm{b}_{1}-\mathrm{b}_{4} & =\text { Koefisien Regresi } \\
\mathrm{e} & =\text { Error }
\end{array}
$$

\section{HASIL PENELITIAN DAN PEMBAHASAN}

\section{Hasil Penelitian}

Pengujian secara simultan (uji F) dilakukan untuk mengetahui apakah semua variable independen $\mathrm{X}_{\mathrm{i}}$ (budaya 
organisasi, kepuasan kerja, motivasi kerja dan lingkungan kerja) secara signifikan pada variable dependen simultan memiliki pengaruh yang kinerja karyawan (Y) pada PT Garuda Indonesia Kantor Cabang Makassar.

Tabel 1. Analisis Anova

\begin{tabular}{llrrrrr}
\multicolumn{7}{c}{ ANOVA $^{\mathbf{b}}$} \\
\multicolumn{1}{l}{ Model } & Sum of Squares & df & Mean Square & F & \multicolumn{1}{c}{ Sig. } \\
\hline 1 & Regression & 13.635 & 4 & 3.409 & 38.702 & $.000^{\mathbf{a}}$ \\
& Residual & 7.927 & 90 & .088 & & \\
& Total & 21.562 & 94 & & &
\end{tabular}

a. Predictors: (Constant), Lingkungan Kerja, Motivasi Kerja, Budaya Organisasi, Kepuasan Kerja

b. Dependent Variable: Kinerja Karyawan

Sumber: data diolah, Tahun 2017

Tabel 1 menjelaskan bahwa semua variable independen $X_{i}$ (budaya organisasi, kepuasan kerja, motivasi kerja dan lingkungan kerja) berpengaruh positif dan signifikan terhadap variable dependen Y (kinerja karyawan) pada PT Garuda Indonesia
Kantor Cabang Makassar. Nilai $F_{\text {hitung }}$ sebesar 38,702 dengan level signifikansi 0,000 atau nilai $p_{\text {value }}<$ 0,05 . Pengaruh simultan variable $X_{i}$ terhadap variable $\mathrm{Y}$ dapat diketahui juga dari koefisien determinasi serentak $\left(\mathrm{R}^{2}\right)$ sebagai berikut:

\section{Tabel 2. Analisis Determinasi}

\section{Model Summary}

\begin{tabular}{|c|c|c|c|c|c|c|c|c|c|}
\hline \multirow[b]{2}{*}{ Model } & \multirow[b]{2}{*}{$\mathrm{R}$} & \multirow[b]{2}{*}{$\begin{array}{c}\mathrm{R} \\
\text { Square }\end{array}$} & \multirow[b]{2}{*}{$\begin{array}{l}\text { Adjusted } \\
\text { R Square }\end{array}$} & \multirow{2}{*}{$\begin{array}{l}\text { Std. Error } \\
\text { of the } \\
\text { Estimate }\end{array}$} & \multicolumn{5}{|c|}{ Change Statistics } \\
\hline & & & & & $\begin{array}{l}\text { R Square } \\
\text { Change }\end{array}$ & $\begin{array}{c}\mathrm{F} \\
\text { Change }\end{array}$ & df1 & $\mathrm{df} 2$ & $\begin{array}{c}\text { Sig. F } \\
\text { Change }\end{array}$ \\
\hline 1 & $.795^{a}$ & .632 & .616 & .29678 & .632 & 38.702 & 4 & 90 & .000 \\
\hline
\end{tabular}

a. Predictors: (Constant), Lingkungan Kerja, Motivasi Kerja, Budaya Organis

Sumber: data diolah, Tahun 2017

Dari Tabel 2 di atas menunjukkan bahwa nilai $\mathrm{R}^{2}=0,632$. Ini berarti, pengaruh variable $\mathrm{X}_{\mathrm{i}}$ (budaya organisasi, kepuasan kerja, motivasi kerja dan lingkungan kerja) secara simultan terhadap variable $\mathrm{Y}_{\mathrm{i}}$ (kinerja karyawan) adalah $63,2 \%$ dan pengaruh variable lainnya sebesar $36,8 \%$.

Tabel 3. Koefisien Regresi

\begin{tabular}{|c|c|c|c|c|c|c|}
\hline \multicolumn{7}{|c|}{ Coefficients $^{\mathrm{a}}$} \\
\hline & & \multicolumn{2}{|c|}{$\begin{array}{c}\text { Unstandardized } \\
\text { Coefficients }\end{array}$} & \multicolumn{3}{|l|}{$\begin{array}{c}\text { Standardized } \\
\text { Coefficients }\end{array}$} \\
\hline \multicolumn{2}{|c|}{ Model } & B & Std. Error & Beta & $\mathrm{t}$ & Sig. \\
\hline \multirow[t]{5}{*}{1} & (Constant) & .139 & .468 & & .298 & .766 \\
\hline & Budaya Organisasi & .261 & .086 & .222 & 3.046 & .003 \\
\hline & Kepuasan Kerja & .514 & .112 & .529 & 4.608 & .000 \\
\hline & Motivasi Kerja & .529 & .074 & .495 & 7.176 & .000 \\
\hline & Lingkungan Kerja & .288 & .110 & .280 & 2.615 & .010 \\
\hline
\end{tabular}

a. Dependent Variable: Kinerja Karyawan 
Dari Tabel 3 terlihat bahwa secara parsial, semua variable analisis memiliki probabilita (level signifikansi) yang berbeda-beda.

1. Variabel budaya organisasi memiliki pengaruh positif dan signifikan terhadap kinerja karyawan pada PT Garuda Indonesia Kantor Cabang Makassar, berdasarkan hasil pengujian secara parsial dengan menggunakan nilai $t$, ditemukan nilai t-hitung untuk variabel budaya organisasi sebesar 3,046 dengan tingkat signifikansi 0,003 $(\mathrm{p}<5 \%)$. Hasil pengujian ini menyimpulkan bahwa hipotesis untuk variabel budaya organisasi yang telah diajukan didukung oleh bukti empirik dalam penelitian ini.

2. Variabel kepuasan kerja memiliki pengaruh positif dan signifikan terhadap kinerja karyawan pada PT Garuda Indonesia Kantor Cabang Makassar, berdasarkan hasil pengujian secara parsial dengan menggunakan nilai $t$, ditemukan nilai t-hitung untuk variabel kepuasan kerja sebesar 4,608 dengan tingkat signifikansi 0,000 ( $\mathrm{p}<5 \%$ ). Hasil pengujian ini menyimpulkan bahwa hipotesis untuk variabel kepuasan kerja yang telah diajukan didukung oleh bukti empirik dalam penelitian ini.

3. Variabel motivasi kerja memiliki pengaruh positif dan signifikan terhadap kinerja karyawan pada PT Garuda Indonesia Kantor Cabang Makassar, berdasarkan hasil pengujian secara parsial dengan menggunakan nilai $t$, ditemukan nilai t-hitung untuk variabel motivasi kerja sebesar 7,176 dengan tingkat signifikansi 0,000 $(\mathrm{p}<5 \%)$. Hasil pengujian ini menyimpulkan bahwa hipotesis untuk variabel motivasi kerja yang telah diajukan didukung oleh bukti empirik dalam penelitian ini.
4. Variabel lingkungan kerja memiliki pengaruh positif dan signifikan terhadap kinerja karyawan pada PT Garuda Indonesia Kantor Cabang Makassar, berdasarkan hasil pengujian secara parsial dengan menggunakan nilai $t$, ditemukan nilai t-hitung untuk variabel lingkungan kerja sebesar 2,615 dengan tingkat signifikansi 0,000 $(\mathrm{p}<5 \%)$. Hasil pengujian ini menyimpulkan bahwa hipotesis untuk variabel lingkungan kerja yang telah diajukan didukung oleh bukti empirik dalam penelitian ini.

Dari hasil analisis yang diperoleh semua variable yang memiliki koefisien regresi berbeda nyata dengan nol, atas dasar hasil tersebut, persamaan regresi yang diperoleh dapat dipakai untuk melakukan pendugaan statistik, termasuk untuk melakukan peramalan dan persamaan regresi yang diperoleh adalah :

$$
\begin{aligned}
Y= & 0,139+0,261 X_{1}+0,514 X_{2} \\
& +0,529 X_{3}+0,288 X_{4}
\end{aligned}
$$

1. Koefisien $b_{0}=0,139$ artinya apabila variabel budaya organisasi $\left(\mathrm{X}_{1}\right)$, kepuasan kerja $\left(\mathrm{X}_{2}\right)$, motivasi kerja $\left(X_{3}\right)$ dan lingkungan kerja $\left(\mathrm{X}_{4}\right)$ tidak mengalami perubahan (konstan), maka kinerja karyawan (Y) pada PT Garuda Indonesia Kantor Cabang Makassar akan tetap sebesar 0,139.

2. Koefisien $b_{1}=0,261$ artinya setiap peningkatan variabel budaya organisasi $\left(\mathrm{X}_{1}\right)$, maka diharapkan dapat meningkatkan kinerja karyawan (Y) pada PT Garuda Indonesia Kantor Cabang Makassar.

3. Koefisien $b_{2}=0,514$ artinya setiap peningkatan variabel kepuasan kerja $\left(\mathrm{X}_{2}\right)$, maka diharapkan dapat meningkatkan kinerja karyawan (Y) pada PT Garuda Indonesia Kantor Cabang Makassar.

4. Koefisien $b_{3}=0,529$ artinya setiap 
peningkatan variabel motivasi kerja $\left(\mathrm{X}_{3}\right)$, maka diharapkan dapat meningkatkan kinerja karyawan (Y) pada PT Garuda Indonesia Kantor Cabang Makassar.

5. Koefisien $b_{4}=0,288$ artinya setiap peningkatan variabel lingkungan kerja $\left(\mathrm{X}_{3}\right)$, maka diharapkan dapat meningkatkan kinerja karyawan (Y) pada PT Garuda Indonesia Kantor Cabang Makassar.

\section{Pembahasan}

Hasil analisis regresi berganda dari penelitian ini menunjukkan bahwa diantara variable independen yang diteliti meliputi budaya organisasi, kepuasan kerja, motivasi kerja dan lingkungan secara simultan berpengaruh positif dan signifikan terhadap kinerja karyawan pada PT Garuda Indonesia Kantor Cabang Makassar. Dari keempat variable tersebut, motivasi kerja merupakan variable yang paling dominan berpengaruh terhadap kinerja karyawan pada PT Garuda Indonesia Kantor Cabang Makassar karena memiliki nilai Beta Standardized Coefficients yang paling besar dibandingkan variabel lainnya. Pengaruh tiap variable independen terhadap kinerja karyawan pada PT Garuda Indonesia Kantor Cabang Makassar diuraikan sebagai berikut:

\section{Pengaruh Budaya Organisasi terhadap Kinerja Karyawan}

Hasil penelitian ini menunjukkan bahwa semakin baik budaya organisasi maka semakin baik pula kinerja karyawan pada PT Garuda Indonesia Kantor Cabang Makassar. Hal ini dapat diketahui dari mayoritas tingkat loyalitas karyawan dalam mengembangkan budaya organisasi tinggi, sehingga karyawan dapat melaksanakan tugas perusahaan dengan baik. Selain itu para karyawan juga diarahkan oleh pimpinan agar dapat bekerja untuk mencapai visi dan misi organisasi, dan para karyawan pun telah bekerja sesuai visi dan misi yang telah dibuat oleh perusahaan. Hal ini membuktikan bahwa karyawan PT Garuda Indonesia Kantor Cabang Makassar selalu berusaha melakukan yang terbaik untuk perusahaannya. Hal ini sesuai dengan pendapat Mangkunegara (2012) yang menyatakan bahwa budaya organisasi adalah seperangkat asumsi atau system keyakinan, nilai-nilai dan normanorma yang dikembangkan dalam organisasi yang dijadikan pedoman tingkah laku bagi anggotanya untuk mengatasi masalah.

Penelitian ini didukung oleh penelitian yang dilakukan oleh Suzanna (2006) yang menunjukkan betapa pentingnya menanamkan budaya inovatif pada PT Astra Agro Lestari, Tbk dan selalu mengkaitkannya dengan kualitas serta ketepatan waktu akan berdampak positif terhadap pertumbuhan tingkat produktivitas yang diharapkan, sehingga hal ini menjadikan PT AAL disaat kondisi perekonomian yang terpuruk tetap mampu untuk memberikan kontribusi bagi pendapatan perusahaanya. Hal ini sesuai dengan penelitian yang dilakukan Orpen (1997) dalam Rina (2010) yang meneliti berkenaan dengan upaya organisasi meningkatkan kinerja dengan melakukan kegiatan forum curah pendapat sehingga meningkatkan interaksi antar anggota dan juga kedekatan dengan anggota yang lain.

\section{Pengaruh Kepuasan Kerja terhadap Kinerja Karyawan \\ Hasil penelitian ini menunjukkan} bahwa karyawan PT Garuda Indonesia Kantor Cabang Makassar merasa puas akan pekerjaannya, puas akan pembayaran, puas akan promosi yang diberikan dan dukungan yang diterima dari atasan, sehingga membuat karyawan tersebut berkinerja baik 
karena kepuasan yang dirasakan oleh karyawan telah membuat karyawan termotivasi untuk bekerja dan meningkatkan kinerjanya. Hal ini sesuai dengan pendapat Umar (2009) yang mengatakan bahwa kepuasan kerja adalah perasaan dan penilaian seorang atas pekerjaannya, khususnya mengenai kondisi kerjanya, dalam hubungannya dengan apakah pekerjaanya mampu memenuhi harapan, kebutuhan, dan keinginannya.

Dalam hubungannya dengan kinerja, kepuasan yang diperoleh oleh karyawan tersebut dapat memberikan pengaruh yang positif terhadap kinerja mereka. Penelitian ini dukung oleh penelitian Yudianto (2008) yang menyatakan bahwa kepuasan kerja berpengaruh terhadap kinerja karyawan dengan indikator teman sekerja yang berarti adanya keharmonisan dalam hubungan dengan rekan kerja, dimana para karyawan saling bekerja sama demi kemajuan bersama, senang jika menerima bantuan, saran, dorongan untuk maju.

\section{Pengaruh Motivasi Kerja terhadap Kinerja Karyawan}

Hasil penelitian ini menunjukkan bahwa karyawan pada PT Garuda Indonesia Kantor Cabang Makassar mempunyai motivasi kerja yang tinggi. Hal ini ditunjukkan dari minat yang tinggi terhadap pekerjaannya. Para karyawan bekerja sesuai dengan apa yang menjadi keinginannya, senang bekerja dan merasa bahwa kebijakan dari pimpinan sesuai dengan keinginannnya. Tingginya motivasi ini juga ditunjukkan dari sikap positif terhadap organisasi. Para karyawan merasa senang apabila pekerjaannya mencapai target yang ditetapkan oeh perusahaan, ditunjukkan pula dengan tingkat kehadiran yang tinggi dan apabila tidak hadir, para karyawan meminta ijin terlebih dahulu. Dibuktikan juga dari keinginan untuk mencari pekerjaan di tempat lain yang relatif rendah, namun dari segi rangsangan seperti bonus, tunjangan di luar gaji dirasa para karyawan masih kurang. Namun demikian, secara keseluruhan motivasi kerja karyawan dalam kategori tinggi, kondisi inilah yang berpengaruh terhadap tingginya kinerja karyawan.

Hasil penelitian ini juga didukung oleh hasil penelitian yang dilakukan oleh Fitria (2008) yang menyatakan bahwa dari variable independen yang diteliti yaitu disiplin kerja, motivasi kerja, kepemimpinan, kemampuan kerja dan lingkungan kerja, variable motivasi kerja adalah variable yang paling dominan berpengaruh terhadap kinerja. Penelitian ini juga sesuai dengan penelitian yang dilakukan oleh Suzanna (2006) yang menemukan dampak dari motivasi dengan mengembangan instrinsik karyawan yang berdampak lebih kuat dari variable lainnya sehingga peningkatan motivasi baik melalui kesesuaian gaji, promosi jabatan maupun dukungan pekerjaan akan meningkatkan kinerja karyawan karena dengan terpenuhinya apa yang menjadi harapan karyawan akan mendorong karyawan untuk bekerja lebih teliti, cakap dan rapih. Sebab motivasi yang tinggi dalam bekerja akan bersumbangsih pada kinerja yang lebih baik.

\section{Pengaruh Lingkungan Kerja terhadap Kinerja Karyawan}

Hasil penelitian ini menunjukkan bahwa semakin baik lingkungan kerja, maka semakin baik pula kinerja karyawan pada PT Garuda Indonesia Kantor Cabang Makassar. Hal ini dapat diketahui dari kinerja karyawan yang semakin meningkat setiap tahunnya, yang dibuktikan dengan peningkatan kinerja karyawan dalam segala kegiatan dan peningkatan pertanggungjawaban serta memberikan nilai tambah kepada stakeholders. Hal ini tidak terlepas dari kondisi 
lingkungan kerja yang ada disekitar karyawan yang dapat mempengaruhi dalam menjalankan tugas-tugas yang dibebankan, sebab kondisi lingkungan kerja yang nyaman, aman dan tenang serta didukung oleh peralatan yang memadai membuat karyawan betah untuk bekerja.

Hasil penelitian sesuai dengan pendapat Nitisemito (2012), kondisi lingkungan kerja yang baik yang ditandai oleh baiknya peredaran udara yang cukup, penerangan lampu yang terang dan jauh dari kebisingan suara yang mengganggu konsentrasi kerja, tata ruang yang baik dan warna yang indah, serta kebersihan yang terjaga sangat membuat pegawai betah bekerja. Lingkungan kerja yang seperti itu akan meningkatkan semangat dalam bekerja. Lingkungan kerja yang terdapat pada PT Garuda Indonesia Kantor Cabang Makassar adalah lingkungan kerja fisik dan lingkungan kerja non-fisik. Lingkungan kerja fisik meliputi tata ruang, penerangan, pertukaran udara serta kebisingan, sedangkan lingkungan kerja non-fisik meliputi tingkat keselamatan dan kesehatan kerja, suasana dalam lingkungan kerja serta komunikasi kerja.

\section{Simpulan}

\section{PENUTUP}

Berdasarkan hasil penelitian dan pembahasan yang telah dikemukakan, maka simpulan dalam penelitian ini adalah :

a. Budaya organisasi berpengaruh positif dan signifikan terhadap kinerja karyawan pada PT Garuda Indonesia Kantor Cabang Makassar. Hal ini berarti semakin baik budaya organisasi maka semakin meningkat kinerja karyawan.

b. Kepuasan kerja berpengaruh positif dan signifikan terhadap kinerja karyawan pada PT Garuda Indonesia Kantor Cabang Makassar.
Hal ini berarti kepuasan kerja yang dirasakan oleh karyawan akan meningkatkan kinerja karyawan.

c. Motivasi kerja berpengaruh positif dan signifikan terhadap kinerja karyawan pada PT Garuda Indonesia Kantor Cabang Makassar. Hal ini berarti motivasi kerja dapat memberikan semangat kepada karyawan untuk meningkatkan kinerjanya.

d. Lingkungan kerja berpengaruh positif dan signifikan terhadap kinerja karyawan pada PT Garuda Indonesia Kantor Cabang Makassar. Hal ini berarti lingkungan kerja yang kondusif dapat meningkatkan kinerja karyawan.

\section{Saran}

Berdasarkan simpulan dalam penelitian ini, maka dapat dikemukakan saran-saran, sebagai berikut:

a. Dalam usaha meningkatkan kinerja karyawan pada PT Garuda Indonesia Kantor Cabang Makassar, maka seluruh variable independen yang terdiri dari budaya organisasi, kepuasan kerja, motivasi kerja dan lingkungan kerja harus mendapatkan perhatian dari pihak pimpinan perusahaan. Oleh karena variable-variabel independen tersebut berpengaruh secara simultan dan signifikan terhadap kinerja karyawan pada PT Garuda Indonesia Kantor Cabang Makassar, maka variable tersebut perlu mendapatkan perhatian yang sama agar apa yang menjadi tujuan perusahaan dapat tercapai dengan baik.

b. Motivasi kerja merupakan variable yang paling dominan berpengaruh terhadap kinerja karyawan PT Garuda Indonesia Kantor Cabang Makassar, untuk itu pimpinan harus lebih memperhatikan variable tersebut karena apabila pimpinan berhasil memberikan motivasi kerja 
kepada karyawan, maka kinerja karyawan akan meningkat secara proporsional.

c. Hasil penelitian ini sifatnya sementara dan mengandung keterbatasan, maka para peneliti selanjutnya menggunakan variabel lain yang dianggap berpengaruh terhadap kinerja karyawan atau menambah lebih banyak variabel dalam melakukan penelitian dan analisis.

\section{DAFTAR PUSTAKA}

Darodjat, Achmad Tubagus. (2015) . Konsep-Konsep Dasar Manajemen Personalia. Bandung: Anggota Ikapi.

Fitria Megawati Kastor. 2008. Analisis Berbagai Variabel Yang Berpengaruh Terhadap Kinerja Aparatur Pemerintah Desa Di Kabupaten Buru. Tesis. PPs UMI.

Gomes, Faustino Cardoso. 2008. Manajemen Sumber Daya Manusia. Penerbit: Andi. Yogyakarta.

Handoko, H.T. 2008. Manajemen Personalia Dan Sumber Daya Manusia. Penerbit: BPFE. Yogyakarta.

Hartatik, Indah P. 2014. Buku Praktis Mengembangkan SDM. Cetakan Pertama. Penerbit: Laksana. Yogyakarta.

Hasibuan, Malayu S.P. 2011. Manajemen Sumber Daya Manusia. Penerbit: PT.Haji Masagung. Jakarta

Kreitner, Robert dan Angelo Kinicki. 2011. Perilaku Organisasi. Edisi Terjemahan, Penerbit Salemba Empat, Jakarta.

Maltis, L. Robert. 2011. Manajemen Sumber Daya Manusia. Buku dua Edisi Indonesia. Salemba Empat. Jakarta.
Mangkunegara, Anwar Prabu , 2012. Evaluasi Kinerja SDM. PT. Refika Aditama, Bandung.

Martoyo, Susilo, 2014, Penilaian Produktivitas Kerja, Penerbit Gramedia Pustaka Utama. Jakarta.

McShane, Steven L. dan Mary Ann Von Glinow,. 2008, Organizational behavi-or, Edisi ke-4, McGraw-Hill, New York.

Moeheriono. 2012. Perencanaan, Aplikasi, dan Pengembangan Indikator Kinerja Utama (IKU) Bisnis dan Publik. Penerbit: Rajagrafindo Persada. Jakarta.

Mondy, R Wayne. 2010. Human Resource Management. Fourth Edition. Ally Bacon. USA.

Nitisemito, Alex S. 2012. Manajemen Sumber Daya Manusia. Penerbit: Ghalia Indonesia. Jakarta

Priansa, D Juni dan Garnida Agus. 2013. Manajemen Perkantoran Efektif, Efisien dan Professional. Bandung: Alfabeta

Rina. 2010. Pengaruh Budaya Organisasi, Kepuasan Kerja dan Motivasi Kerja Terhadap Kinerja Karyawan Pada PT Semen Tonasa. Tesis. Universitas Muslim Indonesia

Rivai. Veithzal. 2009. Manajemen Sumber Daya Manusia Untuk Perusahaan Dari Teori ke Praktek. PT. Rajagrafindo Jakarta.

Robins P. Stephen. 2008. Perilaku Organisasi. Edisi-10. Terjemahan Benyamin Molan. PT Indeks Kelompok Gramedia, Indonesia.

Sedamaryanti. 2011. Sumber Daya Manusia dan Produktivitas Kerja. Penerbit: CV Mandar Maju. Bandung. 
Siagian, Sondang. 2012. Manajemen

Sumber Daya Manusia. Ed.1, Cet. 20, penerbit Bumi Aksara, Jakarta.

Sinambela,. Lijan Poltak., 2012. Reforamasi Pelayanan Publik. Jakarta: Penerbit PT Bumi Aksara.

Suzanna Josephine Tobing. 2006. Pengaruh Budaya Organisasi, Kepuasan Kerja dan Motivasi Terhadap Komitmen Organisasi dan Kinerja (Study pada PT. Astra Agro Lestari Tbk, Jakarta). Disertasi. Fekon Universitas Kristen Indonesia. Jakarta.

Robbins, Stephen P. 2008. Manajemen. Penerbit: Erlangga. Jakarta.

Robbins, Stephen $\mathrm{P}$ dan Judge, Timothv A. 2011. Perilaku Organisasi Organizational Behavior Edisi 12. Jakarta : Selemba Empat.

Singh, Jitendra Kumar dan Mini Jain. (2013). A Study of Employee Job Satisfaction and Its Impact on Their Performance. Journal of Indian Research, Vol. 1, No. 4.

Sugiyono. 2013. Metode Penelitian Bisnis (Pendekatan Kuantitatif, Kualitatif, dan $R \& D)$ ). Penerbit: Alfabeta. Bandung.

Umar Husein. 2009. Riset Sumber Daya Manusia. Gramedia Pustaka, Jakarta.

Yudianto Ronni. 2008. Pengaruh Kepuasan Kerja dan Motivasi Kerja Terhadap Kinerja Guru Di SMK Pangudi Luhur Tarcisius Semarang. Fekon: Univ. Negeri Semarang. 